\title{
The Place of the Sahel Region in the Theory of Regional Security Complex
}

\author{
Márton VARGA ${ }^{1}$
}

\begin{abstract}
The theory of regional security complex is one of the main theories of the regional approach of the international security system. The international organisations, the different strategies and concepts use many different definitions for the Sahel region. However, the ongoing changes of the global and the regional security and the complexity of the crisis of the Sahel region bring up the question whether the Sahel region is a unit based on the Regional Security Complex Theory or not? Which countries are part of the Sahel? Can it be treated as a region? In this article I will give my answer to that question.
\end{abstract}

Keywords: Regional Security Complex Theory, regional security, Sahel region, African security

Barry Buzan and Ole Waever presented their thoughts about the Regional Security Complex Theory (RSCT) in Regions and Powers - The Structure of International Security. In this book, Buzan and Waever have continued their work about the new approach of security which was published in Security: A New Framework for Analysis. ${ }^{2}$

In Regions and Powers, we can learn about the theory itself in detail, and also the units of the global system by the theory. In the followings, I will summarise the main parts of the RSCT, examine the African security system and finally present the comparison of the theory and the regional features of the Sahel.

Africa is an everchanging continent, where the social structure, the security system, the challenges of the sustainable peace and development are constantly mutating. ${ }^{3}$ This varied structure challenges the traditional state-based approach and demand the people-based human security and the regional approach also.

\section{Regional Security Complex Theory}

The end of the cold war has changed the international security system fundamentally. New theories, new approaches started to unfold, new relationships, new states appeared in the

PhD student, University of Public Service, Doctoral School of Public Administration Sciences; e-mail: varga. marton1@gmail.com; ORCID: https://orcid.org/0000-0003-1201-5018

2 Barry Buzan and Ole Waever, Regions and Powers - The Structure of International Security (Cambridge: Cambridge University Press, 2003).

3 UN Economic Commission for Africa, 'Conflict in the Sahel region and the developmental consequences', United Nations, December 2016. 
global dynamics after the first years of the 1990s. The relevance of the Regional Security Complex Theory has grown significantly from this time, but the idea was not completely new. As Buzan wrote, some version has already been made about local balances of power, but as a new approach for the international and the global security it was published in People, States and Fear: An Agenda for International Security Studies in the Post-Cold War Era. ${ }^{4}$

The RSCT has given a new level for the analysis which is wider than the level of the states as such; it grants a more complex view. At the same time, it is narrower than the general approach which means that we can examine the particular regions more specifically.

This regional perspective has been highly appreciated after the collapse of the bipolar security system and the unipolar moment. Since the rivalry between the United States of America (USA) and the Soviet Union existed no more, the role of the regional powers increased. The opinion of Waever and Buzan said that the new global security system built up as $1+4+11$. 1 means the only state with global power, the USA. 4 is the number of the great powers: China, Japan, Russia and the European Union (EU). Finally, the security structure contains 11 regions: North American RSC, South American RSC, European RSC, Middle Eastern RSC, West African proto-complex, Horn proto-complex, Central African RSC, Southern African RSC, post-Soviet RSC, South Asian RSC and the East Asian RSC (Map 1).

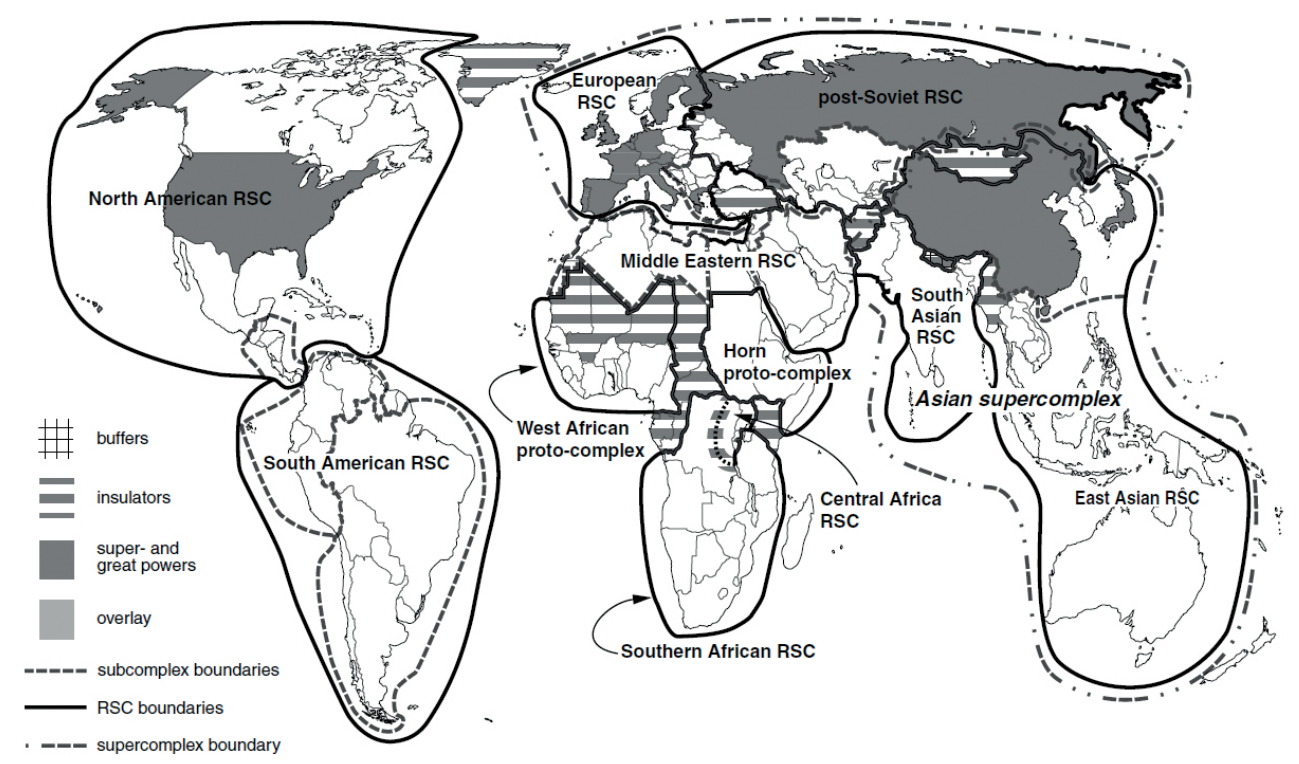

Map 1: The global security structure

Source: Buzan and Waever, Regions and Powers, xxvi.

$4 \quad$ Buzan and Waever, Regions and Powers. 


\section{What is a regional security complex?}

The history of regional security complexes has three parts. ${ }^{5}$ Before 1500 we cannot identify a permanent global level and system; therefore, there were only separated worlds with limited connection between them. The first part lasted from 1500 to $1945 .^{6}$

This period was defined by the European impact, while most of the regions were ruled by European powers as colonisers or had tight connection with them. During these ages, there were not any regions like nowadays, but the whole world was one region under the European imperial powers. After the Second World War, the structure changed, and due to the decolonisation, numerous new states were born or reborn. New dynamics started between the new states and within the regions. In parallel, another process took also place, the building of the bipolar system by the Soviet Union and the USA. That bipolarity was the main principle in the second part from 1945 to 1990. After the fall of the Soviet Union, the third part has begun. This period started with the so-called unipolar moment, with the global power of the USA and has transformed into the multipolar system. ${ }^{7}$ In this international regime, countries lost the safety net even if they officially were not part of the 'western' or 'eastern' block and they had to start to play their own role in the international system.

To understand the RSC, we got two definitions from Buzan and Waever. Buzan's original description from 1983 said: 'A group of states whose primary security concerns link together sufficiently closely that their national securities cannot reasonably be considered apart from one another.' In 1998, the authors redefined it as 'a set of units whose major processes of securitisation, desecuritisation, or both are so interlinked that their security problems cannot reasonably be analysed or resolved apart from one another' ${ }^{8}$ The core of the definition did not change, but it lost the state-centred view and the primarily military based approach. ${ }^{9}$ What does the definition mean? There can be some kind of cultural, historical, economic, religious or geographic link between them, but there has to be some kind of security link also. ${ }^{10}$ In an RSC among the countries, there is security interdependence which defines the RSC itself. These connections can have some negative effects, like fears or progressive dynamics, like aspirations. The security link between the countries not only means that force brings them together, but also means something to differentiate them from the other security regions. ${ }^{11}$

In general, the main features of the countries (political system, geography, culture) can determine the security dynamics of a region. For example, based on the theory of democratic peace, war between democratic states is unlikely. But it is also true, that because of the many differences and the numerous combinations of the features, it is not possible to define clear types of the countries. On the other hand, there is a useable typology to place the state in a spectrum, the spectrum of weak and strong states. In this spectrum we are able to define countries based on the level of their stateness. This stateness means the level of the socio-

\footnotetext{
Barry Buzan, People, States and Fear: An Agenda for International Security Studies in the Post-Cold War Era (Coventry: University of Warwick, Department of International Studies, 1983), 105-114.

6 Buzan and Waever, Regions and Powers, 15.

7 Béla Háda and Péter Tálas (eds), Regionális biztonsági tanulmányok (Budapest: Nemzeti Közszolgálati Egyetem Nemzetközi Intézet, 2014).

8 Buzan and Waever, Regions and Powers, 44.

10 Ibid. 43-44.
}

$9 \quad$ Ibid. 44.

$11 \quad$ Ibid. 48. 
political cohesion of the governmental system and the civil society. In this way, there are strong and weak states according to the sovereignty the state owns. For strong states threats are coming from outside the borders, while weak states have significant internal challenges connected with more vulnerability of outside threats. ${ }^{12}$ The socio-political cohesion is measurable by, for example, the level of democracy, legal reforms, good governance, human rights performance, movement of goods, labour or capital. ${ }^{13}$

Another question is where a country can be positioned on the postmodern, modern and premodern scale of the countries. Modern state stands in the centre of the scale as the Westphalian state type, with strong governmental power and sovereignty, ability to stand against outside influence in economic, political or cultural fields. A modern state is not necessarily a democratic or advanced capitalist state and it can also be weak or strong state.

The main representatives of the postmodern states are the members of the EU. In this category, states are mostly democratic and open minded in the field of culture and economy. Postmodern states build on cross-border cooperation for the interests of the society. In the field of security, the main factor is no more the inside/outside threats but the different structures, links, cooperation between the members to connect them together.

On the other end of the scale we find the premodern states, mostly from Africa and Central Asia. In this category we can see weak states at the beginning of the long road to build a functioning state and also failed states where strong sub-state actors affect security. ${ }^{14}$

According to the above, we can state that in spite of the many differences of the states, the various combinations of inner and outer features and the continuous changing of these means, any RSC can contain weak and strong, and also modern, premodern or postmodern states. These differences are one part of the security dynamics of the RSC.

After the presentation of some usable category of states, we are able to examine the relations between RSCs. Based on the inner relations, there are different forms of the RSCs: rivalry, balance-of-power and alliance. As Buzan and Waever stated, these relations are strongly affected and defined by durable patterns of amity and enmity. These relations are influenced by local and regional connections sometimes with long historical backgrounds.

Buzan and Waever also stated that in their opinion RSCs are mutually exclusive. ${ }^{15}$ That means that we can draw the whole word with RSCs, global actors - who are able to influence more RSCs - and insulator states between larger units or powers (not the same as buffer states ${ }^{16}$ ). Smaller countries usually play only in their RSC with limited capacity to control it. While great powers can define the internal relations and have interests in other connected regions, and they are able to make activities there for their own security. Moreover, superpowers are able to act more freely than great powers and can play a leader role in any RSC.

Every RSC has four essential variables: ${ }^{17}$

1. boundary, which differentiates the RSC from its neighbours

\footnotetext{
Ibid. 20-22.

Ibid. 25.

Ibid. 22-25.

Ibid. 48.

Ibid. 41.

Ibid. 53.
} 
2. anarchic structure, which means that the RSC must be composed of two or more autonomous units

3. polarity, which covers the distribution of power among the units, and

4. social construction, which covers the patterns of amity and enmity among the units

Based on the mentioned attributes, Buzan and Waever differentiated two main and some special forms of the regional security complexes. ${ }^{18}$ The first group of the forms are centred RSCs, which can also divide into more groups, like unipolar or integrated. In the unipolar form, the leader power can be a superpower, like the USA in North America, or a great power like Russia in the Commonwealth of Independent States. The other type of centred RSC is a special form when the security dynamics of a region is mostly influenced by some integrated institutions. The best example of that form is the European Union. ${ }^{19}$ In a centred RSC, we can name a regional or global power who dominates the security agenda of the region.

In contrast with the centred RSC, in a standard RSC we cannot name one power who defines its region. Also, that does not mean, that in standard RSC there are not any regional powers, but without one leading power the security structure is anarchic. Standard RSC can be unipolar, like Southern Africa with the regional power South Africa, or multipolar like South Asia with the two rival power India and Pakistan. These anarchic structures are defined by the relation between the members (rivalries, balances, alliances, friendships).

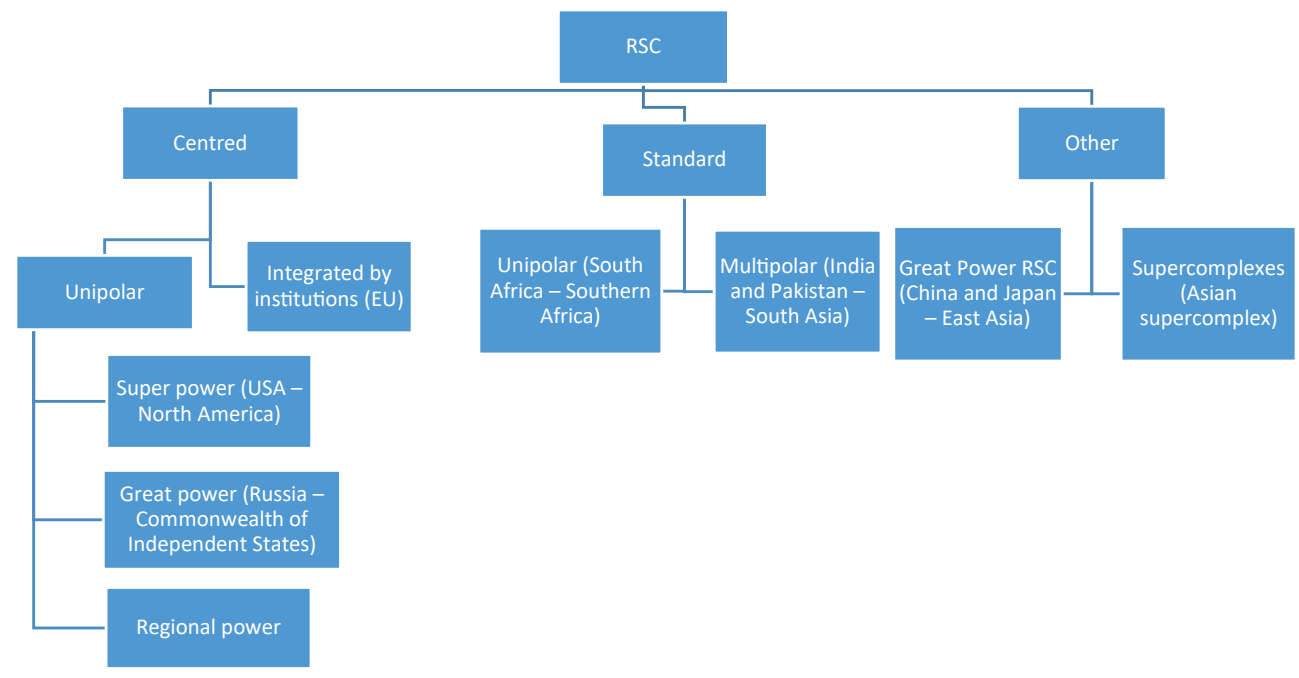

Figure 1: Types of regional security complexes

Source: Compiled by the author. ${ }^{20}$

18 Csaba Vida, ‘A regionális biztonsági komplexum elmélete és alkalmazása Közép-Európára’, Hadtudomány 7 , no 1 (2007), 30-40.

19 Buzan and Waever, Regions and Powers, 54-61.

20 In the Figure I used the examples of Buzan and Waever, Regions and Powers - The Structure of International Security. We must notice, that based on their work, there are many other interpretations of the regions and complexes. For example, the Middle Eastern RSC can be divided into three sub-complexes (Levant, Gulf, Maghreb) or in the Mediterranean region, the Euro-Mediterranean RSC is definable. Éva Remek, 'Az Európai Unió és a Közel-Kelet I.', Nemzet és Biztonság no 5 (2017), 4-30. 
In the global security system, we can find some other special type of the RSC which cannot be categorised into the standard or centred types of RSC. One of the special types is the great power RSC, in which there are at least two global players, the example of this is East Asia with Japan and China. Finally, the other special case is the supercomplex. In a supercomplex, we can find one or more great powers and very complicated security dynamics that has led to a weak interregional level but the superregional took its place. The presented types of RSC can be seen in Figure 1.

After the categories of the regional security complexes, we also have to mention two cases, when the region cannot be put into the mentioned types. The first is the absence of RSC. ${ }^{21}$ There are two situations when RSC cannot be formed or do not form. The first case is overlay, which means that the members of the region cannot form the RSC because the influence of a great power or superpower in the region is too high for the members to operate their own security relations. A good example for this situation is the Cold War Europe influenced by the two superpowers.

The second case of absence is the unstructured RSC. In this case, on the one hand, the countries are not able to project their will on regional level, because they are fragile or failed states with low capabilities. On the other hand, the countries of the regions can be divided from each other geographically (for example, separated islands) and because of this, strong security links cannot be formed. Buzan and Waever said that the Sub-Saharan Africa and the Pacific are good examples for the absence of RSC.

After this short summary of the Regional Security Complex Theory based on Regions and Powers by Barry Buzan and Ole Waever, I will examine the Sahel region from the perspective of the RSCT. The questions are how does the Sahel fit in the RSC theory, are there any links between the countries of the region to form some kind of complex, what region can we exactly call Sahel?

\section{The Regional Security Complex Theory and Africa}

Before I concentrate on the Sahel region based on the RSCT, we have to take a look on the whole continent. In the following, I present how the Post-Cold War African security system was defined in Regions and Powers. According to the structure of RSC built by Buzan and Waever, Africa is divided into two parts. The region of Northern Africa is part of the Middle Eastern RSC, while we have to examine Sub-Saharan Africa as the other part of the continent. In this article, the main focus is on the Sub-Saharan region. (In the following, I will mention Sub-Saharan Africa only as Africa.)

With the European state phenomenon and the idea of the Westphalian state, we can declare that African countries are very young entities with so many difficulties. After their decolonisation, a significant part of African countries could not operate as a well-functioning state. One reason of that was that the new leaders of these countries were not able to use the ideas of 'European' or 'Western' style states. Most of the new African states failed their governmental role as well as their exercising power. With this unstable background and the lack of sovereign power, these states have become unfit to play on the international

21 Buzan and Waever, Regions and Powers, 61. 
level, operate on regional or continental stages. Many countries fell towards personalised regimes, dictatorships or fell prey in the hands of warlords.

I typified the African continent as an ever-changing entity. In Regions and Powers Buzan and Waever presented Africa in the middle of transition after the end of the bipolar global security system. Nearly thirty years have passed since that change and just like the global security environment, the African security has changed a lot too. To investigate today's Africa through the lens of the RSCT, we have to compare the features of African states of the 1990s and nowadays.

The concept of the Weberian state has some vital elements, such as legitimacy and sovereignty. First of all, the power of the state must be based on the general acceptance by the society of the state, its decisions, its administrational system, the monopoly of the state on the necessary fields for example on violence. Legitimacy has three different types, traditional, charismatic and legal-based. Sovereignty is a necessary, inevitable element (conditio sine qua non) of a state. It has two sides, the outer sovereignty which means that the state is independent from other countries, the power of the state is not limited by other countries. The other part is internal sovereignty, which requires that within the boundaries of the state there is not any other state-like power and the state is the only one acting like this. ${ }^{22}$

The creation and the development of the countries of Africa are very different compared to the countries of any other continent. The most important thing we have to mention is that most countries of the post-colonial Africa were not born as a result of some natural process but were created by the former colonisers and great powers. Because of the local specificities, the Westphalian model works in a very different way in Africa. The boundaries drawn by the foreign powers could not have the role of state borders; the ethnic social and political boundaries are more significant. The development of the region was influenced by different ideologies of the end of the twentieth century. The pan-African idea, the 'safety net' that the Organisation of African Union (and later the African Union) meant, and the network of the regional institutions all have a part in the process in which African states did not follow the Westphalian security system with military rivalry and interstate wars. The strong and dense network of the international and regional institutions backed by the UN, other international organisations and different powers made it impossible for the African countries to have the necessary strong impetus to start a military-political competition which is a natural feature of the anarchic international system. For this reason, the security dynamics have developed less dynamically as in other regions. ${ }^{23}$

Comparing the Weberian idea and the post-colonial Africa, legitimacy and sovereignty are at least questionable. The impact of the former colonisers in the creation of the countries undermined the legitimacy and the outer part of sovereignty. In addition, the strong local, ethnic, often traditional and cross-border connections, the military groups, warlords, radical or terrorist groups all make it impossible to create the inner sovereign power by the state.

In the presented security environment, Buzan and Waever have defined the following parts of the African security: Southern African RSC, Central African RSC, West African proto-complex and Horn Proto-complex. The post-Cold War status has showed an evolving

22 Gábor Pál (ed.), Politólógia - Betekintés a politika világába (Budapest: Dialóg Campus Kiadó, 2018).

23 Buzan and Waever, Regions and Powers, 221-222. 
continent, in the middle of great changes. As we can see on Map 2, the authors could define only two concrete RSCs, and a huge part of the continent had an insulator role or formed a proto-complex.

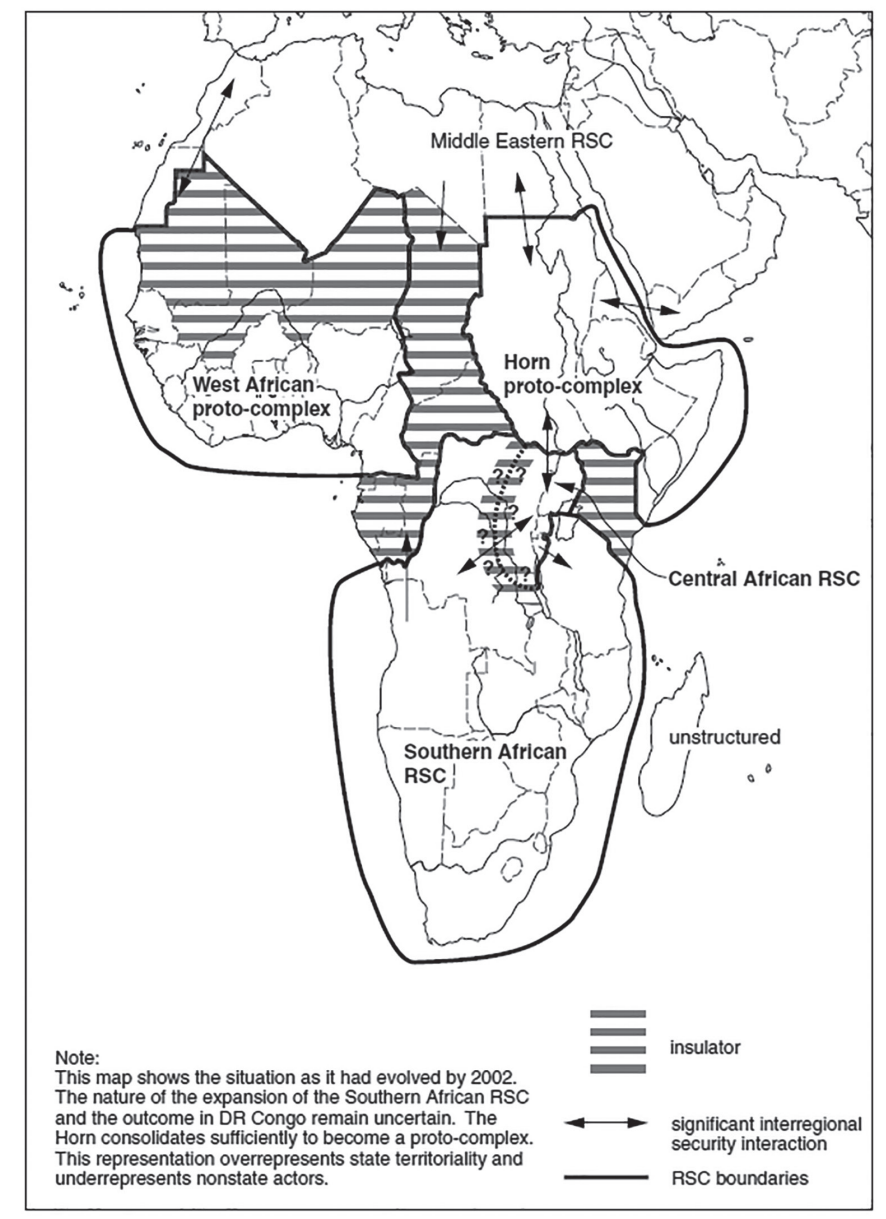

Map 2: The security complexes of Africa

Source: Buzan and Waever, Regions and Powers, 231.

To implement the RSCT on the Sahel region, we have to examine which region is exactly the Sahel. The different international actors, the various disciplines have different concepts about the Sahel. Geography uses a wide definition which says that the Sahel is a semiarid region of western and north-central Africa extending from Senegal eastward to Sudan. ${ }^{24}$ The Sahel is a 5,000-kilometre belt of land below the Sahara Desert, it stretches from Africa's Atlantic coast to the Red Sea, says the UNDP. ${ }^{25}$

24 Encyclopaedia Britannica, 'Sahel'.

25 UNDP, 'Sahel - A region of opportunities'. 


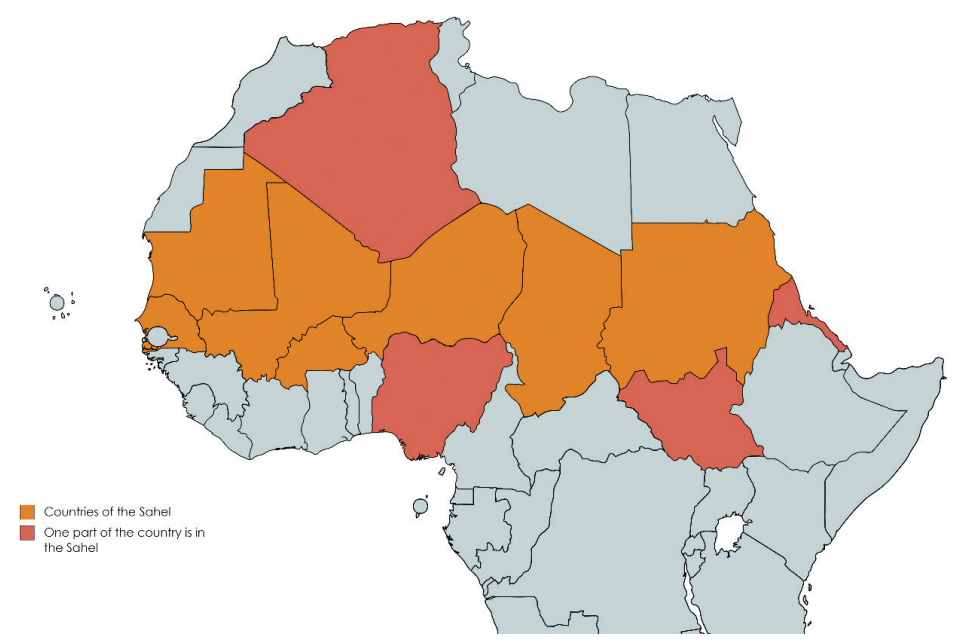

Map 3: The Sahel region in a geographic approach

Source: Compiled by the author.

In contrast, the political approach, the different strategies of the international organisations use a very different definition of the region. I have already mentioned that the UN presented the Sahel as a belt across Africa from East to West. In 2013, they described the region as: 'The Sahel stretches from Mauritania to Eritrea, including Burkina Faso, Chad, Mali, the Niger, Nigeria, Senegal and the Sudan, a belt dividing the Sahara desert and the savannahs to the south.'26 In the UN Support Plan for the Sahel, another group of states is mentioned, which contains only the western countries of the zone (Map 4): Senegal, the Gambia, Mauritania, Mali, Burkina Faso, Guinea, Niger, Nigeria, Cameroon and Chad.

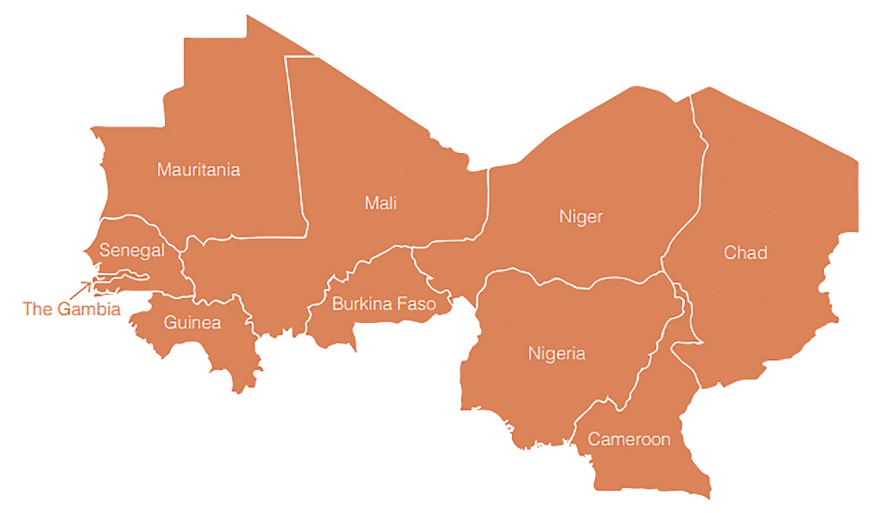

Map 4: The Sahel in the UN Support Plan

Source: United Nations, 'UN Support Plan for the Sahel', May 2018.

26 UN Security Council, 'Report of the Secretary-General on the situation in the Sahel region', United Nations, 14 June 2013. 
In another document, the UN has reduced the number of the states, and only focused on five countries: Burkina Faso, Mali, Niger, Nigeria and Mauritania. ${ }^{27}$

The European Union also has a special strategy for the region. At the beginning, the EU started to cooperate with Mali, Mauritania and Niger, as the countries of the Sahel. In 2014, they extended the list with Burkina Faso and Chad. These five countries created the framework for the cooperation named G5 Sahel (Map 5). ${ }^{28}$

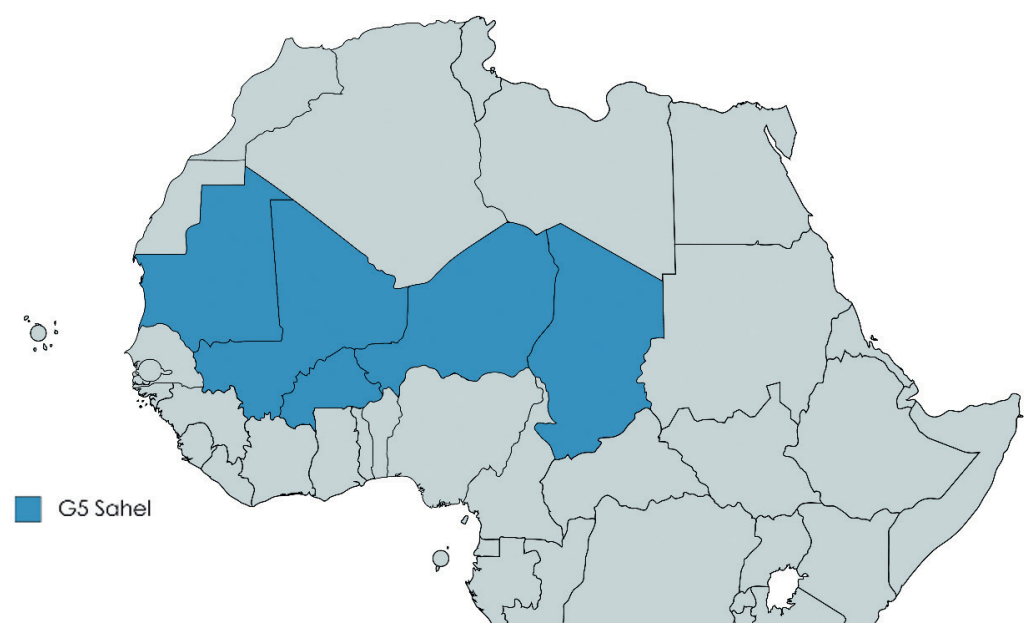

Map 5: The G5 Sahel

Source: Compiled by the author.

The government of Norway also presented a programme to support the Sahel region. In the Strategy for Norway's efforts in the Sahel region 2018-2020, the Sahel refers to Mali, Niger, Mauritania, Chad and Burkina Faso, and to parts of north-eastern Nigeria. ${ }^{29}$ The Norwegian strategy also mentions Algeria, Morocco, Libya and Cameroon as countries with shared characteristics with the Sahel.

These were only a few examples but the differences between definitions and the targeted areas are clear. The question is which Sahel could be the basis of a Sahel complex?

\section{Sahel as a complex}

Africa and the Sahel region have changed a lot in the previous 20-30 years. The postCold War dynamics has transformed, developed, new players and new challenges have appeared. Nowadays, we can see the vulnerable and fragile states, civil wars, radicalisation, famine, human trafficking. The Weberian idea could not come true in these states. However, the number of the non-state actors has increased both on the positive (for example, new

\footnotetext{
UN Economic Commission for Africa, 'Conflict in the Sahel region'. Secrétariat Permanent du G5 Sahel.

29 Ministry of Foreign Affairs, 'Strategy for Norway's efforts in the Sahel region 2018-2020', September 10, 2018.
} 
international organisations, foundations, NGOs) and the negative side (for example, radical and terrorist groups). I have already mentioned the UN and the EU as an example but the African Union, the ECOWAS, the G5 Sahel have also a very important role in the region. All of the different development funds, programmes, action planes strengthen the cohesion between the countries of the region and build the cross-border links, and the regional thinking. In parallel, the radicals, different rebel groups, terrorist organisations (for example, AQIM, ${ }^{30} \mathrm{GSIM}^{31}{ }^{31}$ Boko Haram ${ }^{32}$ and so on) and especially the root causes ${ }^{33}$ of the strengthening of these groups weaken the legitimacy of the states and also question their sovereignty. We also have to admit that we can find countries in Africa, in the Sahel or near the Sahel, who could achieve significant economic growth in the past few years. For example, Ethiopia, Ivory Coast and Senegal are part of the 15 fastest-growing economies in the world in the present and in the 5-year projections, too. ${ }^{34}$ Every country has different opportunities, resources and abilities, and we cannot expect the same development from the countries of the Sahel, but the three mentioned states can be the good example for the countries of the region.

Previously, I used the following definition to the regional security complex: 'A set of units whose major processes of securitisation, desecuritisation, or both are so interlinked that their security problems cannot reasonably be analysed or resolved apart from one another.' Does any one of the Sahel definitions fit for this concept? I also presented four essential variables of the RSC: boundary, anarchic structure, polarity and social construction. How are these realised in the Sahel?

The Sahel in the geographic approach, based on Regions and Powers, belongs to the West African proto-complex, the Horn proto-complex and most countries of the area are insulators. The geographic definition determines a large area, with too many countries. These countries have too many differences (ambitions, priorities, challenges, opportunities) and also the security regime in the western, eastern and central part of the Sahel is very different to form an RSC.

If we exclude the geographic view as the basis of the Sahel security complex, we can examine the area presented in the UN Support Plan. In this zone, we cannot find the structured security links required to form an RSC. This group is still too varied, and the security background of the countries are too different to use the Sahel security complex in this area. Similarly, despite the fact that the West African proto-complex includes

30 AQIM: Al-Qaeda in the Islamic Maghreb. The former GSPC (Groupe Salafiste pour la Prédication et le Combat) joined the Al-Qaeda in 2007. It has become one of the most influential terrorist groups of the Sahara and Sahel region. Gábor Búr, 'Az AQIM, az iszlám Maghreb al-Kaida szervezete', in Afrikai terroristaés szakadárszervezetek, ed. by Álmos Péter Kiss (Budapest: HM Zrínyi Nonprofit Kft., 2015).

31 GSIM: Group for the Support of Islam and Muslims (Jama'at Nasr al-Islam wal Muslimin [JNIM]). In 2017 three terrorist groups, Ansar al-Din, al-Murabitoon and al-Qaeda in the Islamic Maghreb’s (AQIM) Sahara branch unified and formed GSIM. They have fought against France, the 'historical enemy of the Muslim word'. Their main zone of activity is Mali, Niger and Burkina Faso. Center for Strategic \& International Studies, 'Jama'at Nasr al-Islam wal Muslimin (JNIM)', 2018.

32 Boko Haram: The Group of the People of Sunnah for Preaching and Jihad (Jamā'at Ahl as-Sunnah lid-Da’wah wa'l-Jihād) commonly known as Boko Haram. In 2015, Boko Haram's leader pledged allegiance to the Islamic State of Iraq and the Levant, one of the four deadliest terrorist groups in 2017. Institute for Economics \& Peace, 'Global Terrorism Index 2018'.

33 Márton Varga, 'Társadalmi biztonság a terrorizmus árnyékában’, Hadtudomány nos 1-2 (2017), $127-137$.

34 Oliver Reynolds, ‘The World’s Fastest Growing Economies’, Focus Economics, 16 February 2021. 
a significant part of the Sahel, this complex means much more security challenges, links and connections than the Sahel itself.

Finally, the question is whether the G5 Sahel meets the requirements to become some kind of entity by the RSCT. Countries of the G5 Sahel have similar historic, economic, political and security background. This group means a much narrower unit than the other mentioned grouping. In the G5, we can find landlocked countries, except Mauritania. Their territory is defined by not just the Sahel, but the Sahara also. This way, they have very similar economic and commercial opportunities. Their common historical background, as former French colonies, also determine their communities.

The extra factor, which connects these countries is the common enemy. An enemy under the state level and not on the local but the regional level. The enemy are the international terrorist groups, especially the AQIM (Map 6) that has played a decisive role in the region. The radical and terrorist groups in this region can be a strong challenger to the states on the peripheral areas. The states missed to fulfil their duties and created the opportunity for the extremists to integrate themselves into the society. ${ }^{35}$

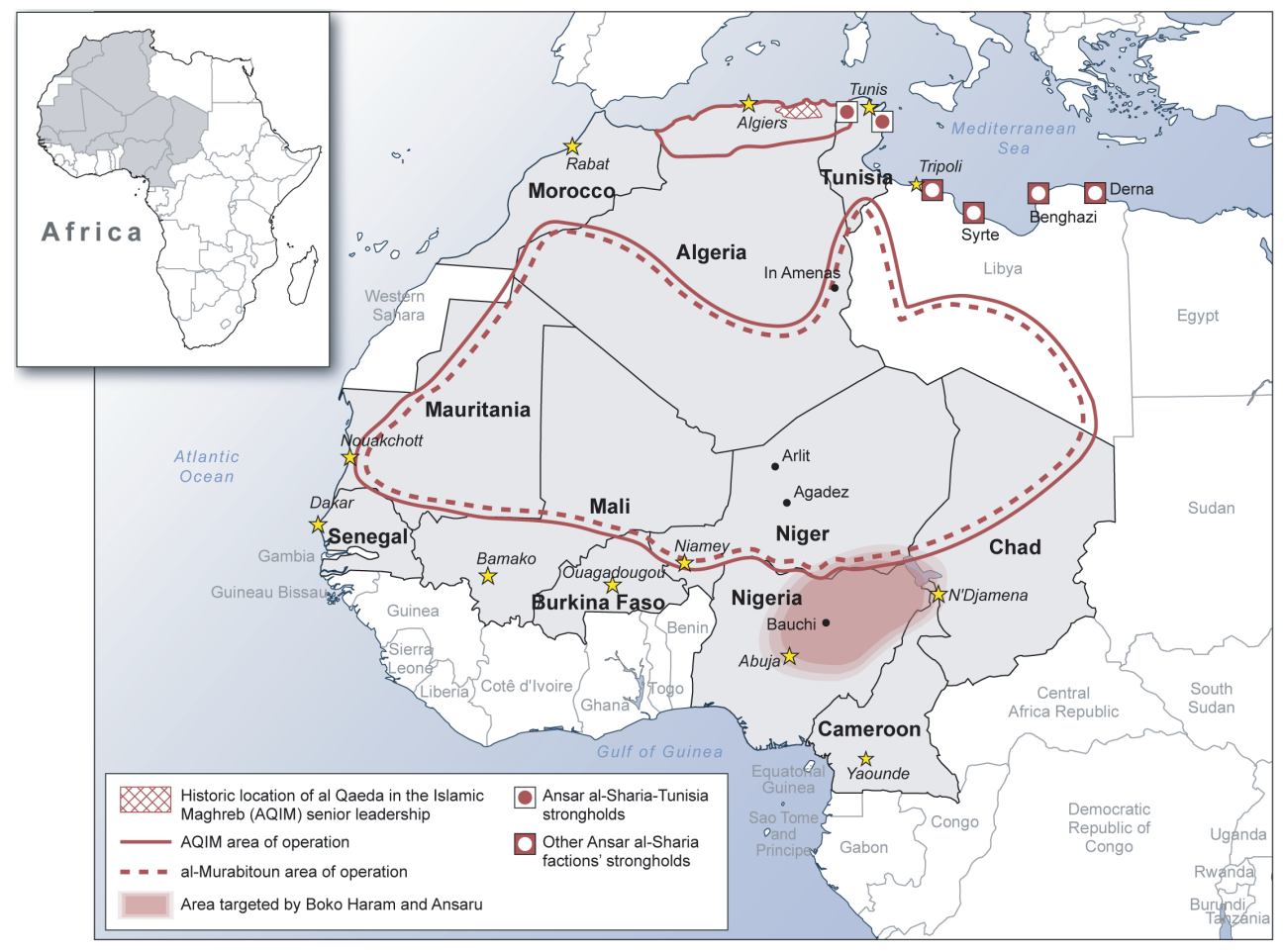

Map 6: Key Terrorist Groups in Northwest Africa and Their Regions of Operation, 2009-2014

Source: United States Government Accountability Office, 'Combating Terrorism. U.S. Efforts in Northwest Africa Would Be Strengthened by Enhanced Program Management’, June 2014.

35 Varga, ‘Társadalmi biztonság a terrorizmus árnyékában’. 
Previously, I have presented four essential elements of an RSC. How do these elements work in the Sahel? The four elements:

1. Boundary, which differentiates the RSC from its neighbours: The geographical definition gives the basis, the cooperation of the G5 Sahel defines the exact borders of the regional unit.

2. Anarchic structure, which means that the RSC must be composed of two or more autonomous units: In the G5 Sahel, we can find five sovereign states and numerous other actors under and above the state level.

3. Polarity, which covers the distribution of power among the units: The main competition is not between the countries, but the actors of the state level and the non-state level.

4. Social construction, which covers the patterns of amity and enmity among the units: Because of the complex challenges of the region, the states are doomed to friendships and cooperation, while the enmity is among the state and the anti-state groups. ${ }^{36}$

As we can see, not all the required elements can be found in the Sahel region, consequently, the Sahel region itself cannot be a separate complex. In Regions and Powers, the countries of the Sahel region were mostly signed as insulators. In the past decades, the region has gone through many decisive events, there were political, economic, societal changes which influenced the security dynamics in the area. As I presented, there are numerous different definitions of the Sahel region, but the common security challenges among the members of the G5 Sahel made them a new entity in the system of the regional security complex. The G5 Sahel has to be defined as a sub-complex in the West African complex. The G5 subcomplex has its own security dynamics that differentiates it from the West African complex and from the other complexes. It has its own organisation that provides the institutional framework for the region.

\section{Summary}

The continent of Africa has a huge amount of difficulties but also opportunities. The ongoing changes are noticeable in every little piece of the African countries' life. The Sahel region has a special role in these processes while there can be found wide interdependent crises in the region. These problems challenge not only the neighbouring countries and the larger international community, but also the theoreticians who are trying to describe the transformations of the security progress with different theories.

In this article, I presented a possible way to describe the Sahel region with the Regional Security Complex Theory. As the conclusion of my examination, the Sahel region can be defined as a regional security sub-complex, which has five member states, Mauritania, Mali, Niger, Burkina Faso and Chad, all of them are part of the G5 Sahel cooperation.

As we can see, Africa mutated significantly since Regions and Powers presented it as a continent mostly with different proto-complexes and a huge number of insulator states. I have also showed several definitions of the Sahel region. Consequently, my interpretation

36 Buzan and Waever, Regions and Powers, 53. 
of the Sahel region describes only the present status. That is why the Sahel sub-complex cannot be a closed group of states.

We also have to admit, that this article has focused on the Regional Security Complex Theory which is based on the state as the main component of a region. As I presented, that kind of state-centred approach has many difficulties in Africa, since this continent developed so very differently than, for example, the European or Asian countries. Based on the experiences, African countries are open to the cooperation within international organisations. This way Africa is more like the South African complex than European. The question is what will be the result in Africa?

The formation of the African countries, the development of the states are very different than the Europeans. In the areas where the tribal or regional connections are stronger than the citizenship, the meaning of the legitimacy and sovereignty and the state-based Weberian concept fails. It is clear, that we have to use these theories more flexible or we need new concepts, as the number of the non-state actors increases, and the number of inner state and cross-border challenges becoming more pronounced.

\section{References}

Búr, Gábor, 'Az AQIM, az iszlám Maghreb al-Kaida szervezete’, in Afrikai terroristaés szakadárszervezetek, ed. by Álmos Péter Kiss. Budapest: HM Zrínyi Nonprofit Kft., 2015.

Buzan, Barry, People, States and Fear: An Agenda for International Security Studies in the Post-Cold War Era. Coventry: University of Warwick, Department of International Studies, 1983, 105-114.

Buzan, Barry and Ole Waever, Regions and Powers - The Structure of International Security. Cambridge: Cambridge University Press, 2003. DOI: https://doi.org/10.1017/ CBO9780511491252

Center for Strategic \& International Studies, 'Jama’at Nasr al-Islam wal Muslimin (JNIM)', 2018. Online: www.csis.org/programs/transnational-threats-project/terrorism-backgrounders/ jamaat-nasr-al-islam-wal-muslimin

Encyclopaedia Britannica, 'Sahel’. Online: www.britannica.com/place/Sahel

Háda, Béla and Péter Tálas (eds), Regionális biztonsági tanulmányok. Budapest: Nemzeti Közszolgálati Egyetem Nemzetközi Intézet, 2014.

Institute for Economics \& Peace, ‘Global Terrorism Index 2018’. Online: http://visionofhumanity. org/app/uploads/2018/12/Global-Terrorism-Index-2018-1.pdf

Ministry of Foreign Affairs 'Strategy for Norway’s efforts in the Sahel region 2018-2020', 10 September 2018. Online: www.regjeringen.no/en/dokumenter/sahel_strategy/id2610507/

Pál, Gábor (ed.), Politólógia - Betekintés a politika világába. Budapest: Dialóg Campus Kiadó, 2018.

Remek, Éva, ‘Az Európai Unió és a Közel-Kelet I.’. Nemzet és Biztonság no 5 (2017), 4-30.

Reynolds, Oliver, 'The World’s Fastest Growing Economies'. Focus Economics, 16 February 2021. Online: www.focus-economics.com/blog/fastest-growing-economies-in-the-world Secrétariat Permanent du G5 Sahel. Online: www.g5sahel.org/ 
UN Economic Commission for Africa, 'Conflict in the Sahel region and the developmental consequences’, United Nations, December 2016. Online: https://repository.uneca.org/ bitstream/handle/10855/23474/b11580410.pdf?sequence=3

UN Security Council, 'Report of the Secretary-General on the situation in the Sahel region', United Nations, 14 June 2013. Online: https://unowas.unmissions.org/sites/default/ files/s_2013_354_sahel_strategy_en_0.pdf

United Nations, 'UN Support Plan for the Sahel', May 2018. Online: www.un.org/africarenewal/ sites/www.un.org.africarenewal/files/English\%20Summary\%20Report_0.pdf

United States Government Accountability Office, 'Combating Terrorism. U.S. Efforts in Northwest Africa Would Be Strengthened by Enhanced Program Management’, June 2014. Online: www.gao.gov/assets/670/664337.pdf

UNDP, 'Sahel - A region of opportunities'. Online: https://feature.undp.org/sahel/

Varga, Márton, ‘Társadalmi biztonság a terrorizmus árnyékában’. Hadtudomány nos 1-2 (2017), 127-137.

Vida, Csaba, ‘A regionális biztonsági komplexum elmélete és alkalmazása Közép-Európára’, Hadtudomány 7, no 1 (2007), 30-40.

Wikipedia, 'Map of the Sahel'. Online: https://upload.wikimedia.org/wikipedia/commons/ thumb/6/69/Map_of_the_Sahel.png/550px-Map_of_the_Sahel.png 